\title{
The visual arts influence in Nazi Germany
}

\author{
Yanan Bie \\ University of Birmingham, Birmingham, England
}

\begin{abstract}
This article will discuss the influence of visual art in Nazi Germany from two parts of visual arts, which are political photography and poster propaganda, analyzing the unique social and historical stage of Nazi Germany. And it emphasizes the ideology of the Nazis, which in Nazi Germany inflamed the political sentiment of the masses and took the visual art as their important instrument of political propaganda, while Nazi party used visual art on anti-society and war which is worth warning and criticizing for later generation.
\end{abstract}

Keywords: visual arts; Nazi Germany; propaganda

\section{INTRODUCTION}

'Nazi Germany' represented the period from 1933 to 1945, which played an important role in prosperous German history and the modern European history. After Germany participated in the First World War in the first half of the 20th century, the whole society was glutted with unemployment, poverty, hunger, inflation and moral corruption. People were disillusioned, angry, humiliated by the harsh treaty of Versailles. In addition to this, their economy was in state of collapse, the government was weak and unstable, and unable to give the country the support it required. The main reason was that people were discomposed that Germany had lost a war and most of the people blamed for the defeat. Besides, during 1929-1933, the worldwide Great Depression impacted Germany, but no leader of Weimar could solve the economic problem. At one time, there were over 16 parties with a minority of seats in government. However, People did not have great faith in the government. Hitler as a leader of the most popular Nazi party, he manipulated people's fear of instability to play a leader with great vision. Hitler and his Nazi party used visual art to grasp the psychology of the masses and also using the visual propaganda gained the support of the worker and the farmer.

Kershaw (1992) offered a definition of visual art in Nazi Germany.

"Visual art, along with films, photos, posters, and advertisements, was heavily shaped by Nazi ideology once Hitler gained power on January $30^{\text {th }} 1933$." Furthermore, visual propaganda was an important instrument during the Nazi Germany for maintaining the power of Nazi policies. Nazis spent huge money on newspapers, poster and campaigns encouraged people to support the party. After 1933s, Nazis controlled the whole country with dictatorship. The characteristic of visual propaganda was combined with visual arts and politics in Nazi Germany, such as political rallies, posters, caricatures, photos and advertisements. In particularly, art was an area that Hitler's particular interested in. Earlier in his life he had attempted to earn his living cost as an artist. In reality, political photography and posters were most prevalent way of propaganda. Rather, photography and posters as more convenient ways were further understood within the relationship between Nazi party and masses.

This article will discuss the influence of visual art in Nazi Germany from two parts of visual arts, which are political photography and poster propaganda, analyzing the unique social and historical stage of Nazi Germany. Additionally, it emphasizes the ideology of the Nazis, which in Nazi Germany inflamed the political sentiment of the masses and took the visual art as their important instrument of political propaganda, while Nazi party used visual art on anti-society and war which is worth warning and criticizing for later generation. Despite an emphasis on the ideology, this article will conclude with significant application for the long-term impact of Nazi propaganda. 


\section{POLITICAL PHOTOGRAPHY SHAPED THE HEAD OF STATES}

\subsection{Political photography in early period}

Before 1933s, the power of Nazi party was extremely weak in process of Weimar political struggle. As David Crew (1946) described, "the First World War left Germany in ruins". People were upset that Germany had lost the war and needed someone to blame for the defeat. As a result, there was enormous violence across the country after the war. Many people blamed the politicians who had negotiated the peace. Many wanted strong leadership. Besides, others merely hoped to get a solution for recovering Germany's economic, political and social problems." Therefore, the Nazi party strengthened the personality cult of head of states by holding some public meetings, demonstrations, general inspections and religious rites. Particularly, worth mentioning is Heinrich Hoffmann, who was a personal photographer of Adolf Hitler for many years, and they worked together to present right images of Hitler to the German public. Moreover, Hitler ordered his The Reich Ministry of Public Enlightenment And Propaganda to document events, because Hitler stressed the importance of propaganda and made speeches in affecting the public.

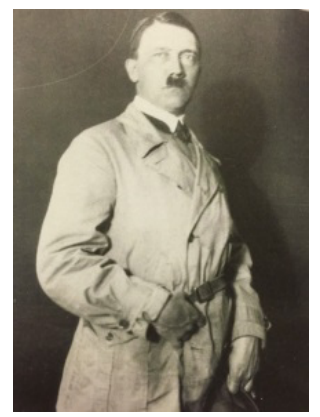

Figure 1. Leader

As the Figure 1 showed, during the election in September 1930, Hitler wore cream-colored wind coat with the glossy hair, especially, the unique body language made him look handsome. Also His shaving formed his brighter image. Based on the political purpose, Hitler would focus on obtaining his position during the meeting and looked down from a height position because it could shape a savior image of masses' will. In other words, the portrait of Hitler was regarded definitely as the future head of state in Germany.

\subsection{Political photography in the middle and later period}

Hitler's portrait gradually changed after 1934, after he took a role as a head of state. For example, judging from the picture, Hitler would rather be photographed in military uniforms with Nazi symbol, which were designed by himself. Hitler was not portrayed as a politician, instead of being seen as above politics. Also, he preferred to lead strong young German males, which has meant that Germany has confidence and power to get a better future. There was an intermediate time before the Second World War (1939). In reality, from 1933 to1939, Hitler announced the Nuremberg Laws which stripped the civil rights of Jews as German citizen. It means that German Jews were faced discrimination and massacre. For example, it was forbidden that any future marriages between Jews and non-Jewish German. Neverthless, Nazi ministry of propaganda utilized the art propaganda let Aryan Germans believe that they were now fighting for their biological enemies. David Crew (2005) points out that "Hitler believed that this racial struggle would inevitably lead to a new world."

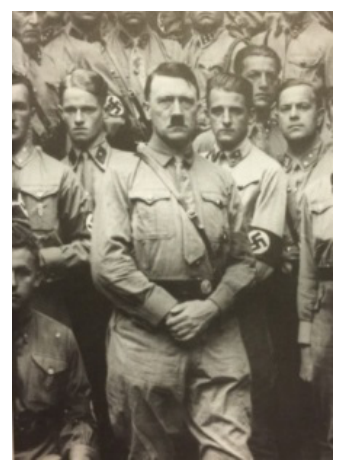

Figure 2 Ready to fight

Furthermore, some pictures presented Hitler's elegant behavior. Hoffman helped Hitler to shape a "Good Guy" and civilian leader Hitler image as seen in the second picture. In the picture which was taken by 1935 , Hoffman realized that Hitler's image should be softened. Therefore, Hoffman planned to present another "human" image of leader. Hitler has responsible for tens of thousands children's life, and this moment that Hitler accompanied some children was recorded. After the Second World War broke out in 1939, Nazis propaganda focused on spreading victorious information in pictures.

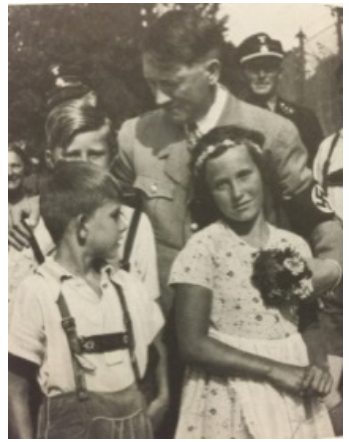

Figure 3.Time with children

The third picture shows that, in 1941, Hitler greeted German soldiers with smiling, which was a candid 
moment of natural behavior. It was not only politician image of the head of state, but also his gentle personality as an average person. Moreover, the Nazi party realized the great value of political visualization, colorization and drama exaggeration, which could control the political ideas of the masses and developed the consciousness of national community through visual art.

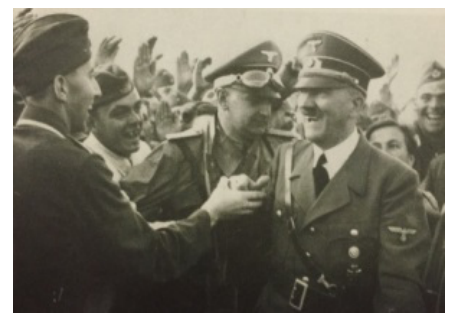

Figure 4.Celebration

\section{POSTER PROPAGANDA PROMOTE EM- PEROR WORSHIP}

Political poster was also used widely as a way for publicity. From 1933 to 1945 , Nazis spent huge money on posters propaganda, which was a nationalized way to show masses. Civilian population through viewing posters they could deeply realize national identity and learned to regard themselves as members of the country. This part will analyze the connection of posters propaganda for worship leaders with policy. There are three main characteristics of posters.

\subsection{Emphasizing the legitimacy of the leader's posi- tion}

At the beginning of the Nazi propaganda, Nazis made posters to shape the Hitler regime legitimacy. Hitler's position was designed as same level as other important leaders. Such as the king (Frederick the Great, 17121786), the prince (O. Von Bismarck, 18151897), the marshal (P.vonHindenburg, 1847-1934).This poster was designed in 1930, which showed that there are leaders from different periods. It put Hitler with emperors in parallel such asking, prince and marshal, which meaning is conveying the German militarism and the supreme spirit of leader. It was specially emphasized the identity of Hitler, who was a soldier. Although the soldiers' status was low compared to other three leaders, that soldier can highlight leader's strong volition and personality charm, therefore, Hitler got the national attention.

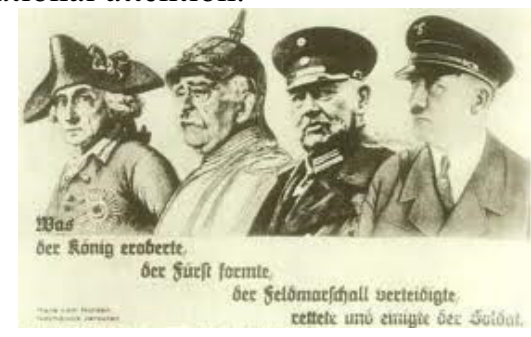

Figure 5.Head of a State

\subsection{Exaggerating the effect of the leader's literature}

According to the poster 'German Book', which released in 1938, Poster promotes Hitler's book 'Mein Kampf'(My struggle), announcing that four million copies have been sold. More specifically, Hitler was in his forties. His book, 'Mein Kampf', (My struggle) was a best-seller. It can be seen the poster, which showed a German map with Hitler's portrait as the cover of Mein Kampf. Moreover, subtitle billed as more than four million copies. There is a evidence that first volume was published in the autumn of 1925 , initially it was far from a bestseller, however, reprinted year after year sales volume increased gradually. From Hitler as prime minister in 1933, the book has sold around one million copies, however, the book was touted as the highest value of literature book sales approximately six million in 1940s.It was becoming the best-selling book in the history of Germany. Putting these together, it could be seen that this poster was simple and powerful, and it strengthened a relationship between the state and the leader. Even if this poster exaggerated the leader's works, the confidence of masses also could be encouraged.

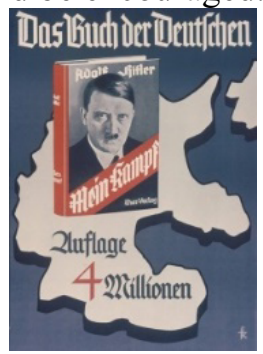

Figure 6. My struggle

\subsection{Building the image of youth tutor}

The Hitler Youth was an important organization for youth in Nazi Germany, and it was partially paramilitary organization. German children were particularly significant propaganda targets, especially through the institutions of schools and education. Hitler often emphasized that the future of Nazi Germany would its children. In other word, Hitler believes that next generation was significant for Germany. Hitler said: "The weak must be chiselled away. I want young men and women who can suffer pain. A young German must be as swift as a greyhound, as tough as leather, and as hard as Krupp's steel.” Kellier. R (2012)

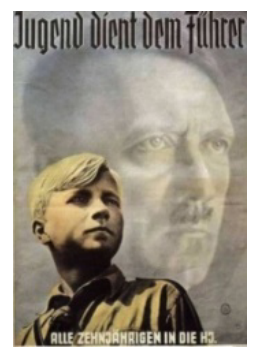

Figure 7 .Youth serves the future-all ten years old should go into the Hitler Youth 
This poster showed a young Aryan-looking member of the Hitler Youth looking up to God-like version of Adolf Hitler. The title was 'Youth serve the future-all ten years old should go into the Hitler Youth' which meaning was encouraging boys as young as 10 years old should serve the leader by joining the organization. Hitler believed that devotion should be fostered as early as possible. Youths were impressionable members of the society, and they were forced to take part in physical activity. The purpose of Hitler Youth was brainwashing young Germany to receive ideology of Nazi Germany.

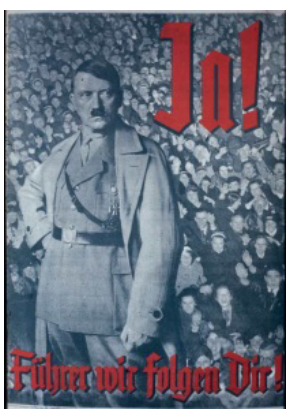

Figure 8. Follow the Leader

The caption reads 'Follow the Leader' that the portrait of Hitler occupied half of the poster behind him with crowded people. Additionally, Ja (Yes) meant that masses will always support and follow Hitler. Based on these factors, the poster uses a way of comparison size to deal with the relationship between Hitler and the masses. Tens of thousands of people appeared in the posters, which showed that Hitler attempted to shape his respectable leader image.

There were two scholars, Heinrich H. (1970) and David Welch(1995). They have a familiar view about Hitler's propaganda, Hitler was all things to a lot of people-although a set of minorities soon found that Hitler didn't just not care about their support, but wanted to persecute, even exterminate them instead, and by changing his message to suit different audiences, but stressing himself as the leader at the top, he began to bind the support of disparate groups together, building enough to rule, modify and then doom Germany. Nazis believed that mixing image or entertainment with propaganda was the most effective way when it was insidious. Therefore, Hitler encouraged the production of poster, which influenced the ambitions of masses and government.

\section{THE IMPACT OF VISUAL ART IN NAZI GERMANY}

The purpose of visual propaganda was to satisfy and convince people, and let masses to believe in the values and decisions of the Nazis. According to above analyses, some results of visual art influenced on people strongly. First of all, this article showed the influ- ence of visual art on young people. There was an organization, Hitler Youth, which was the most important instruments to indoctrinate next generation. The main point of Nazis propaganda was authority. Also, Hitler has own principle that a head of states should play a key role in whole nation, not only represented masses, but also represented all of Aryan Germans. Therefore, people should receive the control without any disagreements. In particular, youth was educated by the authority, even though the education with shocked visual images that will influence young German's physical and psychological health, there was no doubt that Nazi ideology will stay in young German's mind for longtime. For the whole nation, Nazi Youth also was a significant social basis.

Secondly, this article evaluated the influence of visual art on the masses. Photos and posters were two factors in propaganda as well as there were important functions to audiences. Reading newspapers and listening videos could attract people to content, however image was associate with relaxation and envision. David. Welch. (1930) has similar view, Nazis attempted to exert psychological influences by visual propaganda. Also, it was a way familiar with traditional political and cultural thought. The emotional power was aroused and the political sentiment of the masses was inflamed through the emphasis of the individual portrait of Hitler.

Thirdly, the influence of visual art on the Nazi party was analyzed in this article. Hitler attempted to shape his respectable leader image. Besides, Nazis established the greatest success of the propaganda ministry, which managed the entire reign of the Nazi Germany. The Nazis delivered the Nazi messages through the help of the spectacular pictures of the masses rallies, especially the pictures of the conspicuous power. The effects of these meetings and parade were in the early stage, Pictorial image propaganda turned to be more and more important. The Nazi publicists made use of every possibility to turn Hitler's image into deification, idolization and authorization, which was aimed at keeping Hitler's image as a strong ruler. After Germany was defeated in the First World War, people was eager to become a leader who could lead whole country to break away from suffering. The previous section indicates that, during the Election of Nazi party with others, Nazis merely used visual art to gain the vote.

\section{CONCLUSION}

The propaganda minister Joseph Goebbels left a well-known word: "Repeat a lie a thousand times and it becomes the truth." Unfortunately, Goebbels used this principle to operate the black propaganda campaign. Also, Goebbels' propaganda had taken the role for media cult surrounding Hitler. The Nazi party operated propaganda aggressively and proudly. Even 
Hitler himself in 'Mein Kampf (My straggle) 'claimed: "All propaganda must be presented in a popular form and must fix its intellectual level so as not to be above the heads of the least intellectual of those to whom it is directed. (...) The art of propaganda consists precisely in being able to awaken the imagination of the public through an appeal to their feelings, in finding the appropriate psychological form that will arrest the attention and appeal to the hearts of the national masses."

Nazi propaganda, it wasa successful brainwashing way when it tapped into existing political culture and beliefs.Also especially successful when aimed at the young, whose ideas and beliefs had either yet to be formed or were only partially formed.the key reason to support Hitler and the Nazi regime was Hitler himself. Aided greatly by propaganda genius Goebbels, Hitler was able to present an image of himself as a superhuman, even god like figure. Nazi propaganda was very successful in portraying the Germans as supermen and making Hitler seem almost godlike. The Nazi party in order to expand supports of masses, they operated visual propaganda through dramatic political rallies and enormous Nazi symbols, uniforms, flags, posters, caricature and photos. Compared with text, the image was a more impressive way to help masses remember. However Hitler utilized visual arts as an approach to publicize the war and massacre, which were against humanity behavior, warning and criticizing for later generation.

\section{REFERENCES}

[1] Allen. W.S. 1970. Propaganda and welfare in Nazi Germany. Journal of Social History, 4(2): 125-140.

[2] David. C.F. 2005. Hitler and the Nazi: A History in Documents, England: Oxford University Press.

[3] E. Richard. 2005. The Third Reich in Power 1933-1939, England: Penguin Books.

[4] Bytwerk, Randall. 2004. Bending Spines: The Propagandas of Nazi Germany and the German Democratic Republic, Michigan State University.

[5] Heinrich. H. 2012. Hitler was My Friend: The Memoirs of Hitler's Photographer, England: Pen and Sword Books.

[6] Hitler. A. 1939. Mein Kampf Volum II: the National Socialist Movement (English Edition), translated by James Murphy, Archive Media Publishing Ltd.

[7] Kershaw. I. 1992. The Art of Hitler, pp: 49-85.

[8] Kellier. R. 2012. The Omega Paradox, United States: The University of North Carolina Press.

[9] Steinweis. A. 1993. Art, Ideology, Economics in Nazi Germany, United States: The University of North Carolina.

[10] Welch. D. 1983. Propaganda and the German Cinema 1933-1945, England: Oxford University. 